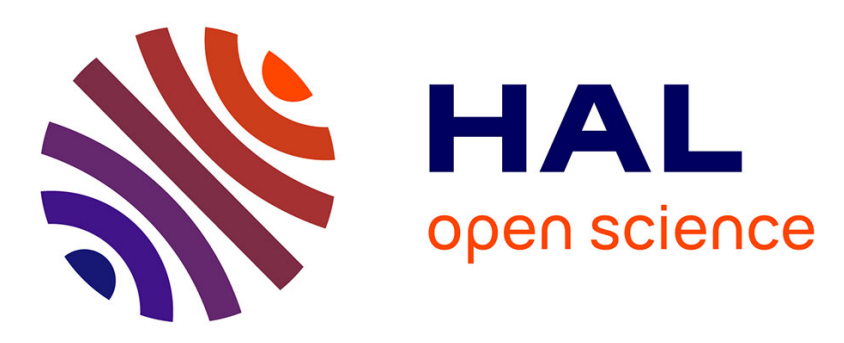

\title{
Transamination at the Crossroad of the One-Pot Synthesis of N-Substituted Quinonediimines and C-Substituted Benzobisimidazoles
}

Judicaelle Andeme Edzang, Zhongrui Chen, Hassib Audi, Gabriel Canard, Olivier Siri

\section{To cite this version:}

Judicaelle Andeme Edzang, Zhongrui Chen, Hassib Audi, Gabriel Canard, Olivier Siri. Transamination at the Crossroad of the One-Pot Synthesis of N-Substituted Quinonediimines and C-Substituted Benzobisimidazoles. Organic Letters, 2016, 18 (20), pp.5340-5343. 10.1021/acs.orglett.6b02640 . hal-01459068

\section{HAL Id: hal-01459068 \\ https://hal.science/hal-01459068}

Submitted on 5 Feb 2020

HAL is a multi-disciplinary open access archive for the deposit and dissemination of scientific research documents, whether they are published or not. The documents may come from teaching and research institutions in France or abroad, or from public or private research centers.
L'archive ouverte pluridisciplinaire HAL, est destinée au dépôt et à la diffusion de documents scientifiques de niveau recherche, publiés ou non, émanant des établissements d'enseignement et de recherche français ou étrangers, des laboratoires publics ou privés. 


\title{
Transamination at the crossroad of the one-pot synthesis of $\mathrm{N}$ - substituted quinonediimines and $\mathrm{C}$-substituted benzobisimidazoles
}

\author{
Judicaelle Andeme Edzang, Zhongrui Chen, Hassib Audi, Gabriel Canard and Olivier Siri* \\ Centre Interdisciplinaire de Nanoscience de Marseille (CINaM), UMR 7325 CNRS, Aix-Marseille Université, Campus de \\ Luminy, case 91313288 Marseille cedex 09 (France)
}

\begin{abstract}
A green and very efficient synthesis of N-substituted benzoquinonediimines or C-substituted benzo-bis(imidazole) derivatives is described under similar conditions. The different reaction pathway is only controlled by the nature of the primary amines which tunes the reactivity of the intermediates.
\end{abstract}

Quinoid compounds are attracting considerable attention because of their specific properties and their numerous applications in a wide spectrum of science. ${ }^{1-4}$ More specifically, benzoquinonediimines (BQI) of type $\mathbf{1}(\mathrm{R}=$ alkyl or aryl) have been extensively investigated because of their remarkable fundamental and applied aspects. The former results from the unique distribution of their overall $12-\pi$ electrons system which is best described as constituted by two 6- $\pi$ electrons subunits chemically connected through two C-C single bonds, but electronically not conjugated (i. e. the so-called "coupling principle"), ${ }^{5}$ giving rise to fascinating optical properties. $^{6}$ The applied aspects correspond to the use of BQI of type $\mathbf{1}$ as reagents in three main axis: (i) in organic chemistry as precursors of benzobisimidazole derivatives, ${ }^{7-9}$ (ii) in analytical chemistry as unusual proton sensors, ${ }^{6,10}$ and (iii) in coordination chemistry as new ligands for the preparation of complexes that recently revealed unprecedented properties for many technological sectors, ${ }^{11-17}$ highlighting the crucial role of the metal center but also and importantly of the N-substituents.

As such, different synthetic strategies giving access to N-substituted BQI 1 have been reported. In 1875, Kimish reported the first preparation by self-condensation of aniline affording 1 with $\mathrm{R}=$ phenyl exclusively (i.e. azophenine, route a, Scheme 1). ${ }^{18}$ In order to extend the nature of the $\mathrm{N}$-substituents, we described in 2000 a stepwise procedure from tetraaminobenzene $2 \cdot 4 \mathrm{HCl}$ which required the need for highly reactive acid chlorides $\mathrm{R}^{\prime} \mathrm{C}(\mathrm{O}) \mathrm{Cl}$ and the use of metallic and strong reducing agents. ${ }^{6,19}$ In addition, this approach affords exclusively $\mathrm{N}$-methylenic molecules $\mathbf{1}\left(\mathrm{N}_{-} \mathrm{CH}_{2}-\mathrm{R}^{\prime}\right)$, limiting the tuning of $\mathrm{R}$ (route $\mathrm{b}$, Scheme 1$)$. To overcome this limitation, Harlan et al. reported in 2004 an efficient alternative based on the Pd-catalyzed aryl amination of the 1,2,4,5-tetrabromobenzene (Buchwald-Hartwig coupling reaction, see route c, Scheme 1). ${ }^{20,21}$ This route allows the use of primary amines with highly versatile R groups, but requires however Pd(II) catalyst which is not environmentally friendly. Finally, Harvey et al. described more recently (2014) another metal-based strategy from benzoquinone and a primary amine catalyzed by $\mathrm{TiCl}_{4}{ }^{22}$

Scheme 1. Syntheses of 1 (limiting factors on the narrows)

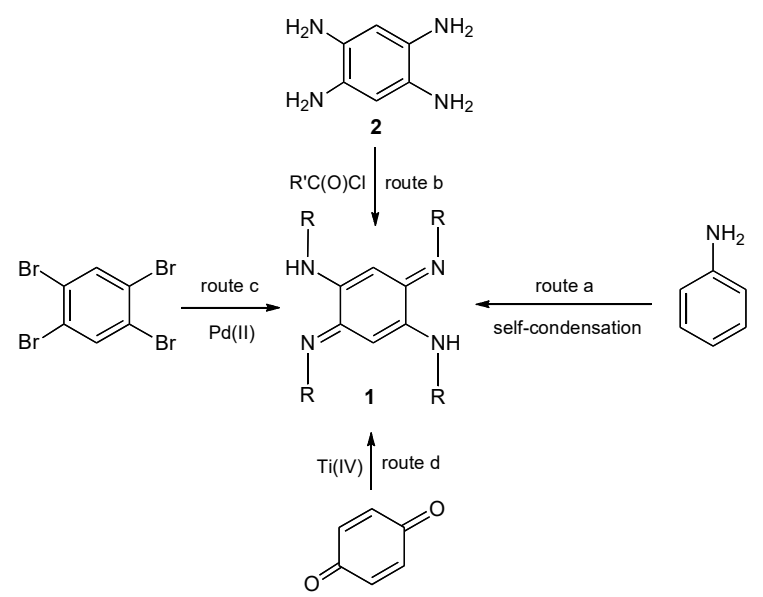

Therefore, elaborating a new synthesis of molecules 1 that would be simultaneously versatile (to overcome route $a, b$ and d) and metal-free (to overcome routes b, c and d) is objectively of major importance in quinoid chemistry. During the course of this work, 
we developed - by serendipity - a new preparation of C-substituted benzobisimidazoles 3 which have recently attracted major interests in numerous applications ranging from photonic ${ }^{8,9,23}$ and sensing ${ }^{24-27}$ to coordination chemistry ${ }^{28,29}$ and materials science. ${ }^{30}$ Molecules 3 have been prepared previously by using three different strategies that revealed drawbacks such as the need of a metal center $^{31}$ and/or of an electrophile of type $\mathrm{R}^{\prime} \mathrm{C}(\mathrm{O}) \mathrm{X}(\mathrm{X}=\mathrm{H} \text { or } \mathrm{Cl})^{8,9,23-27}$ that limits the nature of $\mathrm{R}^{\prime}$.

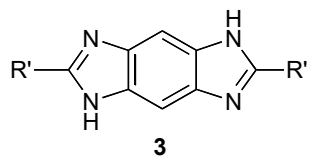

Herein, we report a new and efficient metal-free preparation of $\mathrm{N}$-substituted BQI 1 in MeOH for which the N-alkyl substituents (i.e. the properties) can be easily varied by using a transamination reaction on a key intermediate A1. When the same reaction was conducted with primary amines of type $\mathrm{R}^{\prime}-\mathrm{CH}_{2}-\mathrm{NH}_{2}\left(\mathrm{R}^{\prime}=\right.$ aryl), the formation of unexpected benzobisimidazoles 3 could be observed in good yields.

2.4 $\mathrm{HCl}$ reacted with a large excess of various aliphatic primary amines $\mathrm{RNH}_{2}$ in $\mathrm{MeOH}$ at room temperature under air to form a precipitate that could be isolated by filtration affording BQI 1a-j in 12-88\% yields depending on the nature of R (Scheme 2, route 1). Their ${ }^{1} \mathrm{H}$ NMR spectra showed in solution a structure of high symmetry in agreement with a fast intramolecular double proton transfer involving two degenerate tautomers (See Supporting Information SI). ${ }^{6,32}$ A single crystal X-ray analysis of new 1c confirmed the presence of four alkyl groups and established its p-benzoquinonediimine form (Fig. 1). Examination of the bond distances within the N(1)-C(2)-C(1)-C(3)-N(2) moiety of 1c reveals a localized pi system and a C(2)-C(3) distance of 1.502(4) $\AA$ corresponding to a single bond as already observed for this class of $12 \pi$ - electrons quinones. ${ }^{6}$

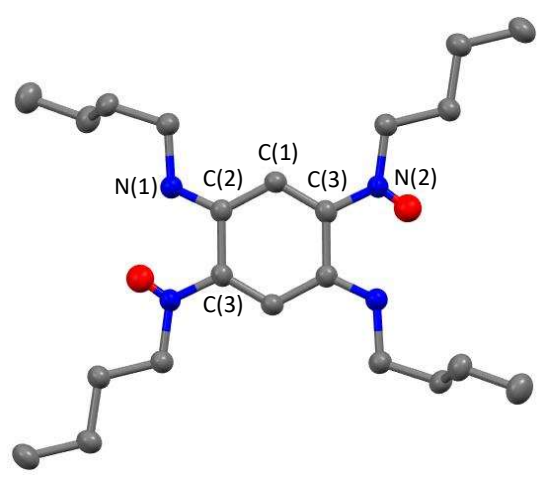

Figure 1. X-ray structure of 1c.

The one-pot formation of the BQI 1a-j can be explained by: i) deprotonation of $\mathbf{2} \cdot 4 \mathrm{HCl}$ in the presence of amines $\mathrm{RNH}_{2} \mathrm{generat}$ ing $\mathrm{RNH}_{3}{ }^{+}$, ii) air oxidation of $\mathbf{2}$ to afford intermediate $\mathbf{4}$ which being more basic than $\mathrm{RNH}_{2}$ can deprotonate in turn $\mathrm{RNH}_{3}{ }^{+}$and form a monocation $\mathbf{A 1}$ that underwent iii) a transamination reaction by nucleophilic attack of $\mathrm{RNH}_{2}$ to give the target compounds of type 1. In order to demonstrate the key role of A1, the synthesis of BQI 1a-j was also carried out directly from $\mathbf{4}^{33}$ in presence of acid $\mathbf{H C l}$, generating in situ the monoprotonated species A1 for which the positive charge is shared between the lower (form A2) and upper (form A3) parts of the molecule (i.e. average structure (A1) in solution resulting from the two tautomers $\mathbf{A 2}$ and $\mathbf{A 3}$ in equilibrium in solution). ${ }^{6}$ Interestingly, the reaction from $\mathbf{4}$ does not proceed in absence of acid supporting the crucial role of the iminium functions in A1 (Scheme 2). This behaviour parallels the case of zwitterionic quinoneimines for which transamination reaction occurs on the positively charged subunit. ${ }^{34,35}$ Reaction with bulky primary amines (for which the amino function is attached to a secondary carbon) could also proceed to give $\mathbf{1 e}, \mathbf{1} \mathbf{h}$ and $\mathbf{1 j}$. Futhermore, this efficient synthesis allows the preparation of BQI $\mathbf{1}$ with interesting functionalities such as $\mathrm{OH}(\mathbf{1 e}$ and $\mathbf{1 f})$ or a $\mathrm{C}=\mathrm{C}$ double bond $(\mathbf{1 h})$ that might be a precursor of choice for polymerization processes. At this stage, three additionnal remarks can be made: i) depending on the nature of the primary amine (i.e. its acido-basic character), transmination reactions on the diprotonated species of $\mathbf{4}$ can not be excluded, ii) in contrast to the related amino $p$-quinones, ${ }^{36}$ partly transaminated compounds could not be isolated owing the need of primary amine $\mathrm{RNH}_{2}$ in excess and the difficult purification of the mixture (only tetra-N-substituted QDIs precipated in solution), and iii) the use of aromatic primary amines did not succeed even under high temperatures and longer time reactions probably due to a weaker nucleophilic character of the amine precursors. 
Scheme 2. Syntheses of 1 and 3: *not isolated<smiles>N=C1C=C([Ge]O)C(=N)C=C1N</smiles><smiles>N=C1C=C(N)C(=N)C=C1N</smiles><smiles>N=C1C=C(N)C(=N)C=C1N</smiles>

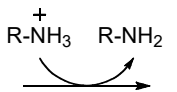<smiles>C1=CC=C1</smiles><smiles>CC1CNc2cc3c(cc2N1)NCN3</smiles><smiles>CC(C)(N)C(C)(C)NN</smiles><smiles>CCC</smiles>
(not isolated)

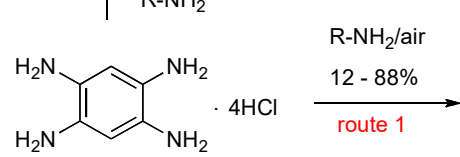
2<smiles>[R]N=C1C=C(N[R])C(=N[R])C=C1N[R]</smiles>

$\mathrm{R}^{\prime}-\mathrm{CH}_{2}-\mathrm{NH}_{2} \downarrow$ route 2<smiles></smiles>

1a: $\mathrm{R}=\mathrm{CH}_{3}$

1c: $: \mathrm{R}=\mathrm{C}_{4} \mathrm{H}_{9}$

1d : $\mathrm{R}=\mathrm{C}_{8} \mathrm{H}_{17}$

1e : $\mathrm{R}=\mathrm{CH}\left(\mathrm{CH}_{2} \mathrm{OH}\right)_{2}$

1f: $\mathrm{R}=\mathrm{CH}_{2}-\left(\mathrm{CH}_{2}\right)_{5} \mathrm{OH}$

6a : $\mathrm{R}^{\prime}=\mathrm{Ph}^{*}$

6b : $\mathrm{R}^{\prime}=3,4,5-(\mathrm{OMe})_{3}-\mathrm{C}_{6} \mathrm{H}_{2}{ }^{*}$

$6 c: R^{\prime}=3-P^{*}$

6d : R' $=2-P y$

1g: $\mathrm{R}=\left(\mathrm{CH}_{2}\right)_{2}-\mathrm{CH}=\mathrm{CH}_{2}$

1h: $: \mathrm{R}=\mathrm{CH}\left(\mathrm{CH}_{3}\right) \mathrm{Ph}$

1j: $: \mathrm{R}=$<smiles>[R]C1Nc2cc3c(cc2N1)NC(CC)C3</smiles><smiles>[R]c1nc2cc3nc([R])[nH]c3cc2[nH]1</smiles>

$3 a: R^{\prime}=P h$

$3 b: \mathrm{R}^{\prime}=3,4,5-(\mathrm{OMe})_{3}-\mathrm{C}_{6} \mathrm{H}_{2}$

$3 c: R^{\prime}=3-P y$

Remarkably, when the same reaction was carried out under similar conditions with primary amines of type $\mathrm{R}^{\prime} \mathrm{CH}_{2} \mathrm{NH}_{2}\left(\mathrm{R}^{\prime}=\operatorname{aryl}\right.$ instead of alkyl group), we now observed the unexpected formation of fluororescent benzobisimidazoles 3a-d in $40-89 \%$ yields (Scheme 2, route 2). These latters could be fully characterized (see SI) including by X-ray diffraction for 3a which showed a anti NH configuration (Fig. 2). This observation contrasts with the syn NH isomer of 3a which was previously determinated resulting from a different packing in the solid state. ${ }^{30}$

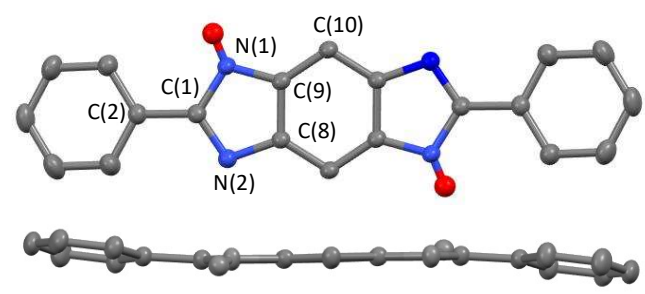

Figure 2. Molecular structure of 3a

The formation of compounds $\mathbf{3 a - d}$ proceeds probably also by transmination reaction from intermediate $\mathbf{A}$ leading to $\mathbf{C}$ which would be then rearranged into $\mathbf{D}$ because of the presence of the aryl group that stabilizes the intermediate by conjugation (Scheme $3)$. D would then be oxidized into $\mathbf{E}$ that underwent a similar rearrangement providing intermediates of type $\mathbf{6}$ that could be isolated in the case of $\mathbf{6} \mathbf{d}($ see SI). 
When $2 \cdot 4 \mathrm{HCl}$ was reacted simultaneously with equimolar quantities of methylamine and benzylamine under similar conditions, we observed the formation of a large mixture of products that could not be separated. This observation suggests similar relative reaction rates between the two primary amines.

Scheme 3. Mechanism for the formation of intermediates 6

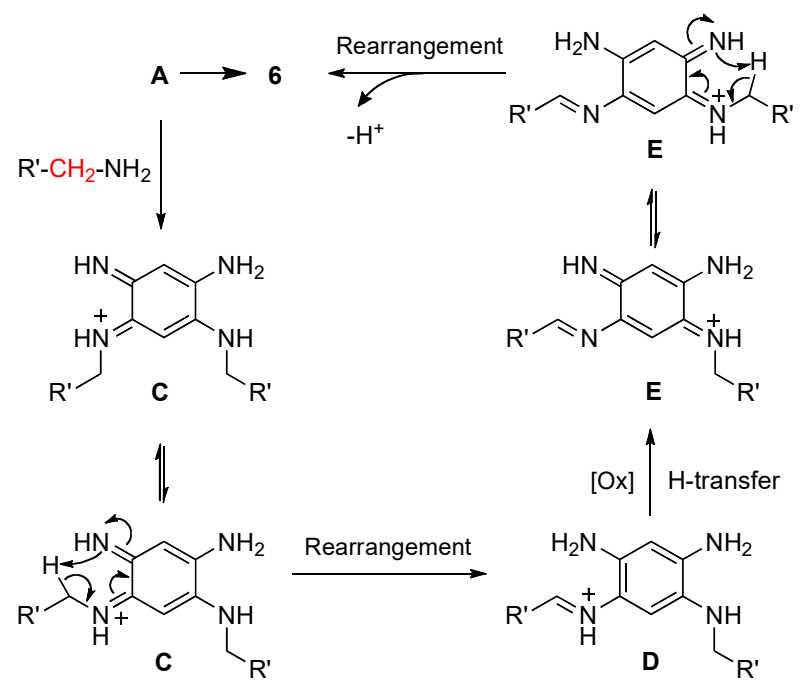

To the best of our knowledge, the isolation of this class of compounds (6) is very seldom reported despite its potential in organic synthesis as 1,3-diaminobenzene precursors (only one exemple reported in the literature). ${ }^{37}$ Intramolecular cyclization of 6a-d in alcohol gives intermediates $\mathbf{B}$ which are readely oxidized under air to afford the C-substituted benzobisimidazoles 3a-d (Scheme 2). The ${ }^{1} \mathrm{H}$ NMR spectrum of $\mathbf{6 d}$ showed the presence of two characteristic resonances at 5.66 and 8.72 ppm corresponding to the amine $\left(\mathrm{NH}_{2}\right)$ and imine $(\mathrm{H}-\mathrm{C}=\mathrm{N})$ protons, respectively. Intramolecular cyclization of $\mathbf{6 d}$ in EtOH could be followed by absorption (Fig. 3) and emission (Fig. S17, see SI) spectroscopy which clearly demonstrated its full conversion into 3d at room temperature (rt). It is noteworthy that this conversion is much faster in presence of water or acid.

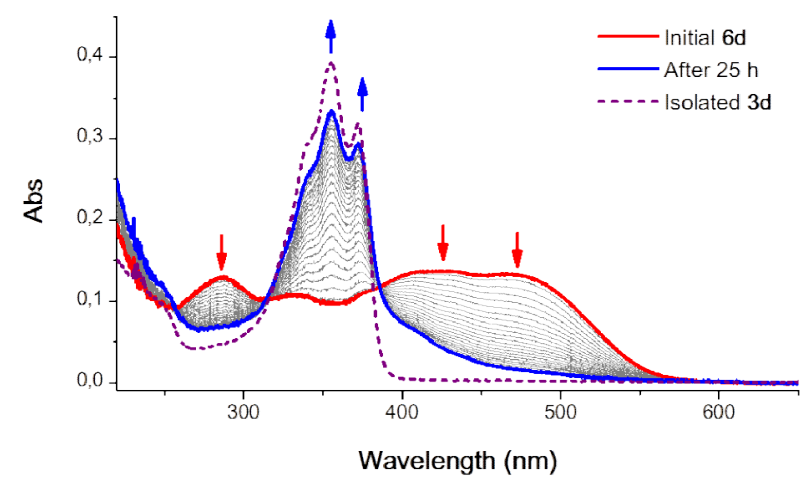

Figure 3. Intramolecular cyclization of 6d into 3d (EtOH at rt)

In conclusion, we described a new synthesis of two major classes of conjugated $\pi$-systems from the commercially available tetraaminobenzene 2. 1) N-substituted BQI 1a-j could be isolated through a transamination reaction on a key cationic intermediate A1. Unlike all the previous routes, our approach is simultaneously versatile and environmentally friendly because it allows the introduction of new functionalities, hitherto unknown, and it proceeds one-pot with no heat and no metal. 2) Benzobisimidazoles 3a-d were also obtained in good yields by using primary amines of type $\mathrm{R}^{\prime} \mathrm{CH}_{2} \mathrm{NH}_{2}$ bearing an aromatic unit ( $\mathrm{R}$ ') that modulates the reactivity (route 1 vs route 2 ). The versatility and simplicity of these "green" approaches pave the way for new perspectives in quinoid chemistry and photonic (benzobisimidazole-based fluorophores).

\section{ASSOCIATED CONTENT}

\section{Supporting Information}


Experimental details and characterization data of the molecules are described. CCDC 1496322 and 1496323 for 3a and 1c, respectively.

\section{AUTHOR INFORMATION}

\section{Corresponding Author}

*olivier.siri@univ-amu.fr

\section{Author Contributions}

The manuscript was written through contributions of all authors. All authors have given approval to the final version of the manuscript.

\section{ACKNOWLEDGMENT}

J. A.E gratefully acknowledges the Agence Nationale des Bourses du Gabon (ANBG) for financial support. This work was supported by the Centre National de la Recherche Scientifique and the Ministère de la Recherche et des Nouvelles Technologies (PhD grant to Z. C.). O.S. thanks Dr Pierre Braunstein (Univ. of Strasbourg) for discussions on transmination reactions. We also thank Valérie Monnier and Christophe Chendo for the analyses by mass spectrometry (Spectropole, Marseille).

\section{REFERENCES}

(1) Pataï, S.; Rappoport, Z. The Chemistry of the Quinonoid Compounds, Vol. 1, Wiley, New York, 1988.

(2) Hettegger, H.; Hosoya, T.; Rosenau, T. Curr. Org. Synth. 2016, 13, 86.

(3) Lopez, J.; de la Cruz, F.; Alcaraz, Y.; Delgado, F.; Vazquez, M. A. Med. Chem. Res. 2015, 24, 359

(4) Moussa, J.; Amouri, H. Angew. Chem. Int. Ed. 2008, 47, 137.

(5) Dähne, S.; Leupold, D. Angew. Chem. Int. Ed. 1966, 5, 984.

(6) Siri, O.; Braunstein, P.; Rohmer, M.-M.; Bénard, M.; Welter, R. J. Am. Chem. Soc. 2003, 125, 13793.

(7) Boydston, A. J.; Khramov, D. M.; Bielawski, C. Tetrahedron Lett. 2006, 47, 5123.

(8) Tasior, M.; Hugues, V.; Blanchard-Desce, M.; Gryko, D. Chem.—Asian J. 2012, 7, 2656.

(9) Shilova, E. A.; Heynderickx, A.; Siri, O. J. Org. Chem. 2010, 75, 1855.

(10) Elhabiri, M.; Siri, O.; Sornosa-Tent, A.; Albrecht-Gary, A.-M.; Braunstein, P. Chem.-Eur. J. 2004, 10, 134.

(11) Sarkar, B.; Schweinfurth, D.; Deibel, N.; Weisser, F. Coord. Chem. Rev. 2015, 293-294, 250.

(12) Jeon, I.-R.; Park, J. G.; Xiao, D. J.; Harris, T. D. J. Am. Chem. Soc. 2013, 135, 16845.

(13) Schweinfurth, D.; Khusniyarov, M. M.; Bubrin, D.; Hohloch, S.; Su, C.-Y.; Sarkar, B. Inorg. Chem. 2013, 52, 10332.

(14) Krupski, S.; Dickschat, J. V.; Hepp, A.; Pape, T.; Hahn, F. E. Organometallics 2012, 31, 2078.

(15) Deibel, N.; Sommer, M. G.; Hohloch, S.; Schwann, J.; Schweinfurth, D.; Ehret, F.; Sarkar, B. Organometallics 2014, $33,4756$.

(16) Ohno, K.; Nagasawa, A.; Fujihara, T. Dalton T. 2015, 44, 368.

(17) Su, Y.; Zhao, Y.; Gao, J.; Dong, Q.; Wu, B.; Yang, X.-J. Inorg. Chem. 2012, 51, 5889.

(18) Kimish, C. Ber. Dtsch Chem. Ges. 1875, 8, 1026.

(19) Siri, O.; Braunstein, P. Chem. Commun. 2000, 2223.

(20) Wenderski, T.; Light, K. M.; Ogrin, D.; Bott, S. G.; Harlan, C. J. Tetrahedron Lett. 2004, 45, 6851.

(21) Khramov, D. M.; Boydston, A. J.; Bielawski, C. Org. Lett. 2006, 8, 1831.

(22) Abdelhameed, M.; Langlois, A.; Fortin, D.; Karsentia, P.-L.; Harvey, P. D. Chem. Commun. 2014, 50, 11214

(23) Boydston, A. J.; Vu, P. D.; Dykhno, O. L.; Chang, V.; Wyatt II, A. R.; Stockett, A. S.; Ritschdorff, E. T.; Shear, J. B.; Bielawski, C. W. J. Am. Chem. Soc. 2008, 130, 3143 .

(24) Zapata, F.; Caballero, A.; Trraga, A.; Molina, P. J. Org. Chem. 2010, 75, 162.

(25) Zapata, F.; Caballero, A.; Espinoza, A.; Trraga, A.; Molina, P. Dalton T. 2010, $39,5429$.

(26) Jain, A. K.; Bhattacharya, S. Bioconjugate Chem. 2011, 22, 2355.

(27) Huang, J.; Li, G.; Wu, Z.; Song, Z.; Zhou, Y.; Shuai, L.; Weng, X.; Zhou, X.; Yang, G. Chem. Commun. 2009, 902.

(28) Yoshimura, A.; Nozaki, K.; Ikeda, N.; Ohno, T. J. Am. Chem. Soc. 1993, 115, 7521.

(29) Ohno, T.; Nozaki, K.; Haga, M. Inorg. Chem. 1992, 31, 4256.

(30) Tomlin, D. W.; Fratini, A. V.; Hunsaker, M.; Adams, W. W. Polymer 2000, 41, 9003.

(31) Zhao, D.; Hu, J.; Wu, N.; Huang, X.; Qin, X.; Lan, J.; You, J. Org. Lett. 2011, 13, 6516

(32) Rumpel, H.; Limbach, H.-H. J. Am. Chem. Soc. 1989, 111, 5429.

(33) Audi, H.; Chen, Z.; Charaf-Eddin, A.; D’Aléo, A.; Canard, G.; Jacquemin, D.; Siri, O. Chem. Commun. 2014, 50, 15140.

(34) Siri, O.; Braunstein, P. Chem. Commun. 2002, 208.

(35) Braunstein, P.; Siri, O.; Taquet, J.-p.; Rohmer, M.-M.; Bénard, M.; Welter, R. J. Am. Chem. Soc. 2003, 125, 12246.

(36) Das, H. S.; Weisser, F.; Schweinfurth, D.; Su, C.-Y.; Bogani, L.; Fiedler, J. Sarkar, B. Chem.-Eur. J. 2010, 16, 2977.

(37) Escudero-Adán, E. C.; Martínez Belmonte, M.; Martin, E.; Salassa, G.; Benet-Buchholz, J.; Kleij, A. W. J. Org. Chem. 2011, $76,5404$. 